\title{
REVIEW
}

\section{Interleukin-17 and Interleukin-23: A Narrative Review of Mechanisms of Action in Psoriasis and Associated Comorbidities}

\author{
Alan Menter · Gerald G. Krueger · So Yeon Paek · Dario Kivelevitch • \\ Iannis E. Adamopoulos · Richard G. Langley
}

Received: December 1, 2020 / Published online: January 29, 2021

(c) The Author(s) 2021

\begin{abstract}
Psoriasis is an immune-mediated inflammatory skin disease associated with numerous inflammatory comorbidities, including increased cardiovascular risk. The interleukin (IL)-23/IL-17 axis plays a central role in the immunopathogenesis of psoriasis and related comorbidities by acting to stimulate keratinocyte hyperproliferation and feed-forwarding circuits of perpetual $\mathrm{T}$ cell-mediated inflammation. IL-17 plays an
\end{abstract}

important role in the downstream portion of the psoriatic inflammatory cascade. This review discusses the distinct mechanisms of action of IL-17 and IL-23 in the immunopathogenesis of psoriasis and related comorbidities plus the significant therapeutic benefits of selectively inhibiting these cytokines in patients with moderate to severe plaque psoriasis.

Keywords: Comorbidities; Cytokines; Inflammation; Interleukin-17; Interleukin-23; Psoriasis

\footnotetext{
A. Menter $(\square) \cdot$ S. Y. Paek · D. Kivelevitch Baylor Scott \& White, Dallas, TX, USA e-mail: amderm@gmail.com

G. G. Krueger

University of Utah, Salt Lake City, Utah, USA

I. E. Adamopoulos

Division of Rheumatology, Allergy and Clinical Immunology, University of California at Davis, Sacramento, CA, USA

R. G. Langley

Dalhousie University, Halifax, NS, Canada
} 


\section{Key Summary Points}

Interleukin (IL)-17 and IL-23 are involved in the immunopathogenesis of psoriasis (PsO) and related comorbidities by acting to stimulate keratinocyte hyperproliferation and feed-forwarding circuits of perpetual $\mathrm{T}$ cell-mediated inflammation.

IL-17 and IL-23 have unique mechanisms of action in the immunopathogenesis of PsO.

Additionally, elevated levels of IL-17 and IL-23 in patients with moderate to severe $\mathrm{PsO}$ promote chronic subclinical inflammation that increases the risk of comorbidities.

Both IL-17 and IL-23 are implicated in PsA pathogenesis; however, IL-17-mediated inflammation may be more central in the development of cardiometabolic comorbidities and axial spondyloarthritis, whereas IL-23 may be more important in IBD immunopathogenesis.

Given the specificity of the IL-23/IL-17A axis in modulating the differentiation and activation of specialized cells involved in skin and joint inflammation, selective blockade of IL-23 and IL-17A is more efficacious than traditional biologic therapies in targeting the psoriatic disease process.

\section{DIGITAL FEATURES}

This article is published with digital features, including a summary slide, to facilitate understanding of the article. To view digital features for this article go to https://doi.org/10.6084/ m9.figshare.13521947. 
axSpA OR psoriasis comorbidities)," "psoriasis pathogenesis" and "psoriasis AND cytokines." Publications detailing the roles of IL-17 and/or IL-23 in the pathogenesis and pathophysiology of PsO, PsA, ankylosing spondylitis (AS), nonradiographic axial spondyloarthritis (nr-axSpA) or associated comorbidities were included. Irrelevant references were excluded from consideration. References cited within the included articles, as well as those previously known to the authors, were considered based on these criteria. This article is based on previously conducted studies and does not contain any studies with human participants or animals performed by any of the authors.

\section{ORIGINS OF THE IL-17 AND THE IL- 23 PATHWAYS}

The IL-17 and IL-23 pathways are central to PsO (Fig. 1) $[15,16]$. TNF- $\alpha$ is a target of four approved $\mathrm{PsO}$ therapies and plays an indirect role in disease pathogenesis by promoting adaptive immune effects of the IL-23/IL-17 axis [17]. The role of IL-23 in PsO onset and continuation is considered to be due to its effects on IL-17-a key effector cytokine of the feedforward inflammatory cycles that perpetuate inflammation [15]. Such signaling loops are the hallmarks of innate immune responses in inflammatory and infectious diseases associated with rash, fever, arthritis, skin inflammation, osteopathies and central nervous system damage [18].

IL-17 has more direct effects on DC distribution and activation than TNF- $\alpha$; however, synergism between IL-17A and TNF- $\alpha$ modulates keratinocyte gene responses in psoriatic lesions $[19,20]$. This interaction is further amplified by IL-17C - the most highly expressed IL-17 in psoriatic lesions [21].

\section{Role of IL-17}

In mammals, IL-17 comprises six homologs that are considered to function as homodimers [22]. IL-17 is produced by Th17 cells in response to stimulation by IL-23 and other cytokines [13].
In addition to Th17 cells, innate lymphoid cells (ILCs), mast cells, neutrophils and $\gamma \delta \mathrm{T}$ cells may be independent sources of IL-17A production in patients with PsO [23]. IL-17A is released from neutrophils and mast cells during specialized immune-mediated cell death in which proteins bind to chromatin threads to form extracellular traps $[24,25]$. However, data are conflicting on whether neutrophils are a major source of IL-17A in PsO; some studies demonstrate IL-17A expression in highly purified human neutrophils, while other studies have failed to detect IL-17A [25-27].

In response to increased IL-17A expression, cells with high concentrations of IL-17 receptors release pro-inflammatory chemokines, cytokines and antimicrobial peptides [28, 29]. The effects of immune cytokines as transcriptional activators of keratinocyte gene products, and auto-antigen stimulation of T-cell responses create feed-forward inflammatory circuits that perpetuate the T-cell activation and inflammation associated with PsO [15]. Stimulation of keratinocytes by IL-17A triggers production of $\mathrm{C}-\mathrm{C}$ motif chemokine ligand 20 , and other chemo-attractants recruit $\mathrm{CCR}^{+} \mathrm{T}$ cells, including IL-17-producing T cells (T17), mature myeloid DCs and other inflammatory cells. This creates a cycle of ongoing inflammatory responses [15, 30]. IL-17A also stimulates keratinocytes to produce IL-19, leading to further keratinocyte proliferation [15]. Cellular levels of the auto-antigens cathelicidin (LL37) and a disintegrin-like and metalloprotease domain containing thrombospondin type 1 motif-like 5 (ADAMTSL5) [31] support this feed-forward hypothesis, as IL-17A blockade decreases levels of LL37- and ADAMTSL5-producing cells in psoriatic lesions [32].

In patients with $\mathrm{PsO}$ in remission, tissueresident memory $\mathrm{T}$ cells in epidermal skin compartments have the ability to maintain and potentially drive disease recurrence [33]. Years after withdrawal of successful PsO treatment, $\mathrm{CD}^{+}$tissue-resident memory $\mathrm{T}$ cells maintain elevated levels of IL-17A, possibly driving inflammation and recruitment of circulating leukocytes into tissue with triggers of disease [33]. It has recently been demonstrated that oligoclonal populations of IL-17-producing $\mathrm{T}$ 
cells remain enriched in clinically resolved psoriatic lesions; of pathogenic T cells identified in active and clinically resolved psoriatic lesions, $\geq 99 \%$ were found to be $\alpha \beta$ T cells [34].

\section{Role of IL-23}

IL-23 is a heterodimeric cytokine that shares a common p40 subunit with IL-12 and a p19 subunit common to IL-23 and IL-39 [35, 36]. The p40 and p19 subunits of IL-23 are overexpressed in PsO plaques, and variations in genes encoding p19 and its receptor are associated with an increased risk of PsO $[35,36]$.

IL-23 is produced by many types of cells, including dermal myeloid DCs, macrophages and epidermal Langerhans cells [15]. It is regulated by Toll-like receptor signaling and is enhanced by TNF- $\alpha$, IFN- $\gamma$ and transcription factors $[37,38]$. The IL-23 receptor (IL-23R) is expressed on memory T cells, natural killer cells, neutrophils, mast cells, ILCs and macrophages [38]. IL-23 binding to its cognate receptor forms an IL-23/IL-23R complex that stimulates ILC differentiation and triggers $\mathrm{CD} 4^{+}, \mathrm{CD}^{+}$and $\gamma \delta$ $\mathrm{T}$ cells to synthesize IL-17 and other pro-inflammatory cytokines [39]. IL-23 also induces macrophages to produce TNF- $\alpha$, stimulates keratinocyte proliferation in the absence of IL-17A and promotes further IL-23R expression, thus creating a self-amplifying loop [15, 39, 40].

\section{Differences Between the IL-17 and IL-23 Pathways}

IL-17A overproduction triggers the perpetual cycle of inflammation that characterizes PsO pathogenesis-which includes a cascade of cytokine, chemokine and antimicrobial peptide actions that induce epidermal hyperplasia-and innate immune responses $[7,15,16]$. IL-23 is a key upstream regulator of IL-17A production by stimulating differentiation, activation, proliferation and survival of Th17 cells. Because IL-23 does not regulate all cellular mechanisms of IL$17 \mathrm{~A}$ production, targeting IL-23 does not seem to increase the risk of candidiasis that has been observed in the small percentage of patients $(<5 \%)$ treated with IL-17A inhibitors $[16,41]$.
However, agents that directly target the IL-17 pathway act more downstream in the psoriatic inflammatory cascade [15], providing a diseasespecific treatment with a rapid onset of action [42-45].

\section{PSORIASIS COMORBIDITIES AND THE ROLE OF IL-17 AND IL-23}

Elevated levels of systemic pro-inflammatory cytokine in patients with moderate to severe $\mathrm{PsO}$ promote chronic subclinical inflammation that increases the risk of comorbidities, including PsA, CV disease, diabetes, obesity, dyslipidemia, hypertension, inflammatory bowel disease (IBD), nonalcoholic fatty liver disease and depression [4, 46, 47]. IL-17 and IL-23 are implicated in PsA pathogenesis; however, IL17-mediated inflammation may be more central in the development of cardiometabolic comorbidities [48, 49] and IL-23 in IBD immunopathogenesis [50].

To treat moderate to severe plaque $\mathrm{PsO}$, six biologic therapies targeting IL-17A or IL-23 are currently approved: secukinumab, ixekizumab, brodalumab, guselkumab, tildrakizumab and risankizumab. Secukinumab is a fully human IgG1 $\kappa$ monoclonal antibody (mAb) [51], and ixekizumab is a humanized IgG4 mAb [52, 53]; these agents selectively bind and neutralize IL$17 \mathrm{~A}$. Brodalumab is a fully human IgG2 $\mathrm{mAb}$ that binds to the IL-17A receptor in a nonactivating manner and thus inhibits IL-17A, IL-17C, IL-17E and IL-17F [54]. Seminal mechanistic studies of inflammatory immune responses elicited by IL-17 and disrupted by anti-IL-17 mAbs have confirmed that IL-17A inhibition blocks pathogenic mechanisms of psoriatic inflammation $[19,55,56]$.

Anti-IL-23 agents include guselkumab, a

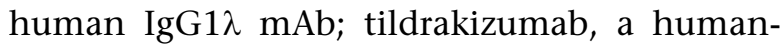

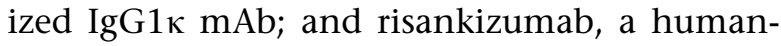
ized IgG1 mAb. Both guselkumab and tildrakizumab bind the p19 subunit of IL-23, preventing formation of a receptor complex $[36,57]$. Risankizumab binds and neutralizes the p19 subunit of IL-23 [58]. Mutations in p19 and its receptor IL-23R are associated with a risk of $\mathrm{PsO}$ [59]. 
The six approved IL-17A and IL-23 inhibitors appear more efficacious than biologic therapies that are less specific such as the four TNF- $\alpha$ inhibitors, adalimumab, etanercept, certolizumab pegol and infliximab, and the single IL-12/23 inhibitor ustekinumab [52, 60-62]. Significant improvements in skin manifestations of psoriatic disease are achieved in approximately $90 \%$ of patients with approved IL-17A or IL-23 inhibitors [63].

Additional IL-17 and IL-23 therapies are in late-stage clinical development. Bimekizumab is a humanized IgG1 mAb that selectively neutralizes IL-17A and IL-17F and is being studied in PsO [64], PsA [65] and axial spondyloarthritis. Mirikizumab is a p19 antagonist of IL-23 under investigation for the treatment of $\mathrm{PsO}$ [66], ulcerative colitis [67] and Crohn's disease (CD) $[39,68]$.

\section{Psoriatic Arthritis}

Approximately $30 \%$ of patients with $\mathrm{PsO}$ develop PsA within 10 years of the onset of their skin disease $[69,70]$. Delay of PsA diagnosis for as little as 6 months can result in permanent joint erosions [71]. These erosions may be evident in $40-60 \%$ of patients within the first year of diagnosis [72], and 55\% of patients have been found to have $\geq 5$ deformed joints over 10 years of disease [70]. Pathogenic features of PsA include elevated synovial fluid levels of IL17 and increased expression of IL-17A receptor by synoviocytes $[12,73]$. Increased levels of IL$17 \mathrm{~A}$ and IL-23 in PsA lead to upregulation of other cytokines (e.g. IL-6 and IL-8), matrix metalloproteinases and the receptor activator of NF-кB (RANK), which are associated with pathogenic changes, bone resorption, bone matrix structure changes and osteoclastogenesis [73-76].

Animal PsA models demonstrate that IL-23 and IL-17 induce skin and joint inflammation, but distinct cellular pathways regulate these outcomes [77]. Axial involvement in PsA is predominantly driven by IL-17 with the induction of RANK ligand and RANK in stromal cells and osteoclast precursors, respectively, leading to pathologic osteoclast differentiation [78-80].
In contrast, IL-23 induces co-stimulatory pathways via immunoreceptors expressed in myeloid osteoclast precursors [81]. The presence and severity of dactylitis and enthesitis are strongly correlated with HLA-B27 misfolding, which triggers upregulation of IL-23 and induction of the IL-17 axis [82]. Experimental models show that upregulation of pro-inflammatory cytokines of the IL-23/IL-17 pathway induce joint swelling, skin changes and nail deformities characteristic of PsA [77]. In a murine model, treatment with IL-17A and IL-17F inhibitors decreased levels of inflammatory cytokines and showed efficacy in treatment of skin inflammation mimicking PsO [83].

IL-17A is central in the pathogenesis of joint destruction and bone erosion in PsA, with elevated levels of IL-17A and/or its receptor in synovial tissue, osteoblasts, osteoclasts and chondrocytes [80, 84]. Studies of secukinumab and ixekizumab support the mechanistic role of IL-17A in PsA immunopathogenesis, as inhibition of this cytokine improves joint symptoms and prevents joint destruction [85]. Patients receiving secukinumab or ixekizumab also report significant improvements in physical functioning and quality of life and achieve complete or near complete skin clearance [53, 86-89]. Secukinumab and ixekizumab are both approved for the treatment of active PsA, and both prevent joint destruction $[90,91]$.

The efficacy of targeted IL-23 inhibition in PsA has been confirmed in large-scale studies. Results from the phase 3 DISCOVER-1 and DISCOVER-2 trials show efficacy of guselkumab in patients with active PsA despite treatment with standard nonbiologic therapies, leading to its recent approval for the treatment of active PsA [92, 93]. Phase 3 studies of tildrakizumab (NCT03552276) and risankizumab (NCT03671148 and NCT03675308) are also ongoing for PsA. The IL-12/23 inhibitor ustekinumab is approved for the treatment of active PsA, despite its non-placebo-adjusted ACR20 scores being $18-35 \%$ lower than those for TNF- $\alpha$ and IL-17A agents approved for PsA (secukinumab and ixekizumab) [62]. In March 2019, risankizumab received its first global approval in Japan for the treatment of adults with PsO and PsA [94], based on positive results from the 
SustaIMM phase $2 / 3$ trial [95]. Injection-site reactions (ISRs) have been recorded in clinical trials of many biologic agents for PsO and PsA, with the majority being of mild to moderate intensity. With adalimumab, etanercept, ixekizumab and guselkumab, ISRs are among the most common adverse events [96-99]. With secukinumab, ISRs affect $<1 \%$ of patients [100], whereas ixekizumab has more frequent and longer-lasting ISRs [98]. Most ISRs for all biologic agents mentioned resolve without any medical intervention; however, persistent ISRs can be treated with oral antihistamines or prevented by switching to another biologic therapy [101].

\section{Cardiovascular and Metabolic Diseases}

Mild and severe PsOs are both associated with an increased risk of myocardial infarction and stroke, while severe $\mathrm{PsO}$ is associated with a significantly increased risk of CV mortality [102]. In three cross-sectional studies, moderate to severe coronary calcification was five times higher in patients with $\mathrm{PsO}$ than in healthy controls and similar to that in patients with type 2 diabetes [103]. CV risk in patients with severe $\mathrm{PsO}$ is independent of traditional risk factors and is associated with significant mortality [104]. The relative risk of CV mortality is 2.69 for a 40-year-old patient with severe PsO versus a matched healthy control [104]. CV disease in patients with $\mathrm{PsO}$ is also associated with an increased prevalence of metabolic disorders; patients with $\mathrm{PsO}$ are more than twice as likely as the general population to have metabolic syndrome [14, 105].

Similarities exist between the pathophysiologies of $\mathrm{PsO}$, atherosclerosis and metabolic syndrome [106]. This includes the immunology and pathology of the activation of myeloid DCs and endothelial cells, promoting differentiation of Th1 and Th17 cells and secretion of pro-inflammatory cytokines such as TNF- $\alpha$, IFN- $\gamma$, IL$17 \mathrm{~A}$ and IL-22 [49, 105]. In PsO and atherosclerosis, IL-17 and TNF- $\alpha$ synergistically activate NF- $\mathrm{kB}$ signaling and mitogen-activated protein kinases to induce neutrophil-attracting chemokines and other inflammation modulators [107, 108]. Using the KC-Tie2 doxycycline-repressible (Dox-off) murine model of psoriasiform skin disease, prolonged elevations in IL-17, TNF- $\alpha$ and C-C motif chemokine ligand-2 have been found to increase aortic inflammation and thrombosis [109]. This thrombosis phenotype can be attenuated upon elimination of skin inflammation with doxycycyline[109] or through inhibition of IL-17A or IL-23 [110]; this effect is potentially mediated by reduction of skin IL-6 [111]. These results suggest that chronic systemic inflammation associated with $\mathrm{PsO}$ is likely the main cause of the increased risk of adverse CV outcomes [109].

IL-17 also contributes to the pathophysiology of hyperlipidemia, hypertension, renal disease and obesity. Increased IL-17 production exacerbates hyperlipidemia by triggering immune responses against oxidized low-density lipoprotein and collagen $\mathrm{V}[112,113]$. In hypertension and renal disease models, IL-17 promotes inflammation by stimulating neutrophil chemo-attractants and increasing renal artery stiffening, possibly through upregulation of type I collagen deposition [114-117]. In obesity, a common issue in patients with moderate to severe PsO, circulating IL-17A promotes production of vascular endothelial growth factor and acts synergistically with adipokines to perpetuate inflammation, angiogenesis and endothelial dysfunction [118].

The phase 4 ObePso-S study (NCT03055494) explored the effects of secukinumab versus placebo on the expression of inflammatory genes in patients with moderate to severe chronic plaque PsO. Preliminary results indicate that treatment responses observed with secukinumab correspond to normalized inflammatory marker and immune cell levels [119]. Another phase 4, open-label study (METABOLYX, NCT03440736) is investigating whether treatment with secukinumab and lifestyle changes can improve metabolic status in patients with PsO with metabolic syndrome; results are expected in 2021.

A series of studies on vascular inflammation in PsO (VIP) is evaluating the effects of biologic therapies on vascular inflammation and $\mathrm{CV}$ biomarkers. In the adalimumab study (VIP-A), TNF- $\alpha$ inhibition reduced levels of the 
inflammatory markers $\mathrm{C}$-reactive protein and IL-6 versus placebo or phototherapy, but not vascular inflammation [120]. In the ustekinumab study (VIP-U), 12 weeks of treatment reduced aortic vascular inflammation by $6.6 \%$ versus a $12.1 \%$ increase with placebo $(P=0.001)$ [121]. However, no differences in aortic vascular inflammation were observed after 52 weeks of ustekinumab treatment [122]. In the secukinumab study (VIP-S), although TNF- $\alpha$ and ferritin levels were reduced and fetuin-A levels increased after 52 weeks of secukinumab treatment (all $P<0.05$ versus placebo), no significant changes in aortic vascular inflammation versus placebo were observed [123].

\section{Axial Spondyloarthritis}

The IL-23/IL-17 axis has been implicated in the pathogenesis of axial spondyloarthritis (axSpA), including AS and nr-axSpA [124, 125]. PsO is observed in $10 \%$ of patients with AS [126]. In patients with AS, genes in the Th17 pathway are overexpressed and serum levels of IL-17 and IL23 are elevated [127]. IL-17A inhibition with secukinumab or ixekizumab significantly reduces signs and symptoms of AS[128-130] and nraxSpA [131, 132]. In contrast, data on the effects of IL-23 inhibition in axSpA are limited. In a phase 2 study, treatment with risankizumab did not improve signs and symptoms of AS versus placebo [133]. The significant efficacy of IL-17A inhibitors in axSpA and the lack of efficacy with the IL-23 inhibitor risankizumab[133] suggest that IL-17A modulates a pathogenic pathway in axSpA, which is independent of IL-23 signaling.

\section{Inflammatory Bowel Disease}

IBD is approximately four times more prevalent in patients with $\mathrm{PsO}$ than in the general population [134], suggesting a genetic overlap of the two diseases [135]. IL-23 has been linked to murine chronic intestinal inflammation, and genome-wide association studies have implicated IL-23 gene variants in IBD [136]. However, contrasting data suggest a role for IL-17A in gastrointestinal homeostasis and tissue repair rather than in driving inflammation as in $\mathrm{PsO}$ pathogenesis [137]. In clinical studies, patients with IBD have achieved significantly higher rates of clinical and endoscopic remission with IL-12/23 or IL-23 inhibitors than with placebo [50]. Ustekinumab is approved for the treatment of moderate to severe active CD and is in late-stage development for ulcerative colitis; IBD trials are also ongoing for several IL-23 inhibitors [138], with positive results reported for risankizumab in CD [139]. Conversely, IL17A inhibitors have failed to demonstrate efficacy in CD, despite their clear efficacy in PsO $[140,141]$. The local environment of Th17 cells in the gut and skin may differ, or IL-23 may act via an IL-17-independent pathway to promote intestinal inflammation in patients with IBD [50]. Although small clusters of new IBD cases have been reported among patients with $\mathrm{PsO}$, PsA or AS using IL-17A inhibitors, IBD events were rare $(<1 \%)$, and their incidence did not increase over time $[135,137,142]$. The effects of IL-17A inhibition on IBD may be two-fold and conflicting, either decreasing inflammation or possibly worsening the residual function of an already impaired epithelial barrier [137].

\section{EXPERT COMMENTARY}

Data from preclinical and clinical studies provide strong evidence that IL-17A and IL-23 are key mechanistic drivers of PsO immunopathogenesis. Targeting IL-17A and IL-23 cytokines provides skin clearance superior to that of currently approved TNF- $\alpha$ inhibitors or ustekinumab [51, 52, 58, 61, 143].

In patients with moderate to severe chronic plaque PsO, treatment with approved IL-17A or IL-23 inhibitors is well tolerated. Complete or near complete skin clearance is seen in the majority of patients [53, 86-88]. Across pivotal $\mathrm{PsO}$ phase 3 studies, $>50 \%$ of treated patients achieved $\geq 90 \%$ improvement in Psoriasis Area and Severity Index scores [63]. Additionally, secukinumab, ixekizumab and guselkumab are effective in more difficult-to-treat disease subtypes, including palmoplantar, scalp, nail and genital PsO [144-149]. Available data for IL-17 inhibitors suggest that primary and secondary nonresponse can be treated by switching to 


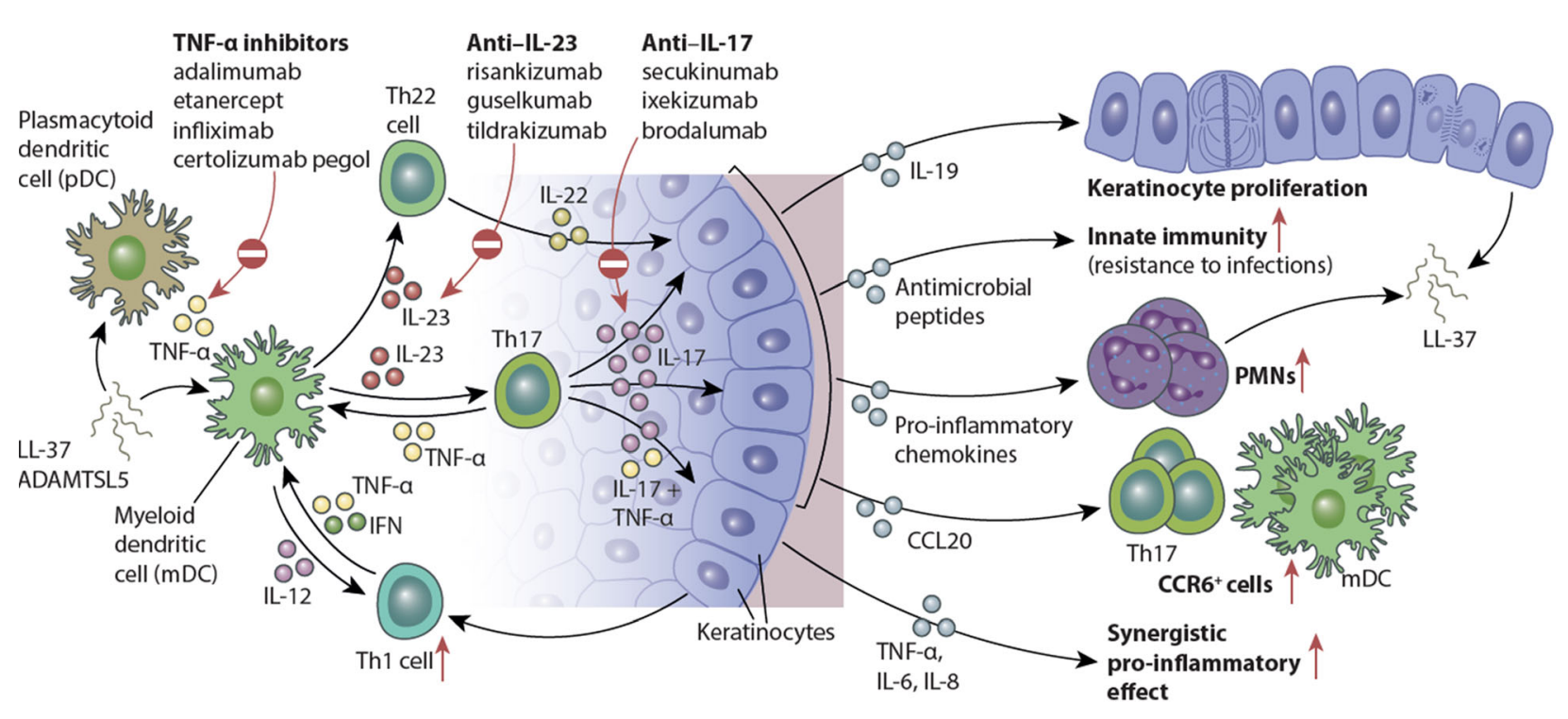

Fig. 1 IL-23/IL-17-mediated effects on epidermal keratinocytes in psoriatic skin. Schematic showing the broad downstream effects of increased IL-23 and IL-17 signaling on various immune cell populations and keratinocyte biology. Regulated by IL-23, the primary effects of IL-17 on keratinocytes include the following: indirect induction of epidermal hyperplasia through cytokines such as IL-19; upregulation of the innate immune response and antimicrobial peptides; epidermal recruitment of leukocyte

biologics within the same class [150, 151], highlighting the centrality of this signaling pathway in PsO.

IL-17A and IL-23 inhibitors are better tolerated than methotrexate and TNF- $\alpha$ inhibitors and show a safety profile comparable to that of ustekinumab [152]. Use of IL-17A inhibitors is associated with an increased risk of mucocutaneous candidiasis ( $<5 \%$ of treated patients), but it does not lead to treatment discontinuation [16]. Reports of neutropenia (0.7 events per 100 patient-years of exposure) and IBD $(<1 \%)$ are rare with approved IL-17A inhibitors [128, 137]. In phase 3 studies of brodalumab, three patients attempted suicide with one completion [153]. No major safety signals have been identified with guselkumab, tildrakizumab or risankizumab. IL-23 inhibitors do not appear to be associated with an increased risk of candidiasis or IBD; however, safety data from real-world registries are needed to confirm the full tolerability of targeted IL-23 inhibition [41, 152]. subsets through increased production of keratinocytederived chemokines; and transcription of multiple proinflammatory genes that act synergistically with tumor necrosis factor (TNF)- $\alpha$ to sustain the inflammatory events in psoriatic skin. $P M N$ polymorphonuclear leukocyte; $T h$ T helper. Adapted from Hawkes JE, et al. J Allergy Clin Immunol. 2017;140(3):645-653. Copyright 2017, with permission from Elsevier

\section{CONCLUSIONS}

IL-17 and IL-23 have unique mechanisms of action in PsO immunopathogenesis, with IL-17 being an important cytokine in the PsO inflammatory cascade. New biologic agents blocking IL-17A and/or IL-23 are more efficacious than traditional biologic therapies that are less specific in targeting the psoriatic disease process. Given the specificity of the IL-23/IL$17 \mathrm{~A}$ axis in modulating the differentiation and activation of specialized cells involved in skin and joint inflammation, selective blockade of IL-23 and IL-17A is more efficacious than traditional biologic therapies. The contribution of each pathologic mechanism to the clinical manifestations of PsO, PsA and other inflammatory comorbidities is currently under evaluation in multiple clinical trials. 


\section{ACKNOWLEDGMENTS}

Funding. The journal's Rapid Service Fee was funded by Novartis Pharmaceuticals Corporation, East Hanover, NJ, USA.

Medical Writing, Editorial, and Other Assistance. The authors thank Richard Karpowicz, $\mathrm{PhD}$, of Health Interactions, Inc, Hamilton, NJ, USA, for providing medical writing support/editorial support, which was funded by Novartis Pharmaceuticals Corporation, East Hanover, NJ, USA, in accordance with Good Publication Practice (GPP3) guidelines (http://www.ismpp.org/gpp3).

Authorship. All named authors meet the International Committee of Medical Journal Editors (ICMJE) criteria for authorship for this article, take responsibility for the integrity of the work as a whole, and have given their approval for this version to be published.

Disclosures. Alan Menter is an investigator for AbbVie, Allergan, Amgen, ApoPharma, Boehringer Ingelheim, Celgene, Convoy Therapeutics, Genentech, Janssen Biotech, Eli Lilly, LEO Pharma, Merck, Novartis, Pfizer, Symbio/ Maruho, and Wyeth; receives research funds from AbbVie, Allergan, Amgen, ApoPharma, Boehringer Ingelheim, Celgene, Convoy Therapeutics, Genentech, Janssen Biotech, LEO Pharma, Merck, Pfizer, Symbio/Maruho, and Syntrix; and is an advisor, consultant, and/or speaker for and received honoraria from AbbVie, Allergan, Amgen, Boehringer Ingelheim, Convoy Therapeutics, Eli Lilly, Genentech, Janssen Biotech, LEO Pharma, Novartis, Pfizer, Syntrix, Wyeth, and XenoPort. Gerald G. Krueger has received fees as a consultant or advisory board member for Abbott, Amgen, Boehringer Ingleheim, Janssen Biotech, Eli Lilly, Novartis, Pfizer, Johnson \& Johnson (PSOLAR), Sun Pharma, and DermTech International; has received lecture fees from Abbott, Amgen, Janssen Biotech, Novartis, and Eli Lilly; and has received partial stipend support for clinical research fellowships from Abbott and the National Psoriasis Foundation. So Yeon Paek has received grants and/or honoraria as an investigator, consultant, and/or speaker for AbbVie, Avillion, Celgene, Janssen, Ortho-Dermatologics, and UCB. Dario Kivelevitch has received honoraria as a speaker for Eli Lilly. Iannis E. Adamopoulos has received consultancy fees/grants from Novartis, Pfizer, Schering-Plough/Merck, and Tanabe Research Laboratories. Richard G. Langley has served and received compensation in the form of grants and/or honoraria as principal investigator for and is on the scientific advisory board or has served as a speaker for AbbVie, Amgen, Boehringer Ingelheim, Celgene, Eli Lilly, Janssen, LEO Pharma, Merck, Novartis, Pfizer, and UCB.

Compliance with Ethics Guidelines. This article is based on previously conducted studies and does not contain any studies with human participants or animals performed by any of the authors.

Open Access. This article is licensed under a Creative Commons Attribution-NonCommercial 4.0 International License, which permits any non-commercial use, sharing, adaptation, distribution and reproduction in any medium or format, as long as you give appropriate credit to the original author(s) and the source, provide a link to the Creative Commons licence, and indicate if changes were made. The images or other third party material in this article are included in the article's Creative Commons licence, unless indicated otherwise in a credit line to the material. If material is not included in the article's Creative Commons licence and your intended use is not permitted by statutory regulation or exceeds the permitted use, you will need to obtain permission directly from the copyright holder. To view a copy of this licence, visit http://creativecommons.org/licenses/by$\mathrm{nc} / 4.0 /$.

\section{REFERENCES}

1. Nestle FO, Kaplan DH, Barker J. Psoriasis. N Engl J Med. 2009;361(5):496-509. 
2. Boehncke WH, Schön MP. Psoriasis. Lancet. 2015;386(9997):983-94.

3. Rachakonda TD, Schupp CW, Armstrong AW. Psoriasis prevalence among adults in the United States. J Am Acad Dermatol. 2014;70(3):512-6.

4. Elmets CA, Leonardi CL, Davis DMR, Gelfand JM, Lichten J, Mehta NN, et al. Joint AAD-NPF guidelines of care for the management and treatment of psoriasis with awareness and attention to comorbidities. J Am Acad Dermatol. 2019;80(4):1073-113.

5. Gelfand JM, Troxel AB, Lewis JD, Kurd SK, Shin DB, Wang $X$, et al. The risk of mortality in patients with psoriasis: results from a population-based study. Arch Dermatol. 2007;143(12):1493-9.

6. Lowes MA, Suárez-Fariñas M, Krueger JG. Immunology of psoriasis. Ann Rev Immunol. 2014;32:227-55.

7. Hawkes JE, Chan TC, Krueger JG. Psoriasis pathogenesis and the development of novel targeted immune therapies. J Allergy Clin Immunol. 2017;140(3):645-53.

8. Clark RA. Gone but not forgotten: lesional memory in psoriatic skin. J Invest Dermatol. 2011;131(2): 283-5.

9. Mahil SK, Capon F, Barker JN. Update on psoriasis immunopathogenesis and targeted immunotherapy. Semin Immunopathol. 2016;38(1):11-27.

10. Swindell WR, Johnston A, Xing X, Voorhees JJ, Elder JT, Gudjonsson JE. Modulation of epidermal transcription circuits in psoriasis: new links between inflammation and hyperproliferation. PLoS ONE. 2013;8(11):e79253.

11. Davidovici BB, Sattar N, Jörg PC, Puig L, Emery P, Barker JN, et al. Psoriasis and systemic inflammatory diseases: potential mechanistic links between skin disease and co-morbid conditions. J Invest Dermatol. 2010;130(7):1785-96.

12. Bravo A, Kavanaugh A. Bedside to bench: defining the immunopathogenesis of psoriatic arthritis. Nat Rev Rheumatol. 2019;15(11):645-56.

13. Boutet MA, Nerviani A, Gallo Afflitto G, Pitzalis C. Role of the IL-23/IL-17 axis in psoriasis and psoriatic arthritis: the clinical importance of its divergence in skin and joints. Int J Mol Sci. 2018;19(2):E530.

14. Lockshin B, Balagula Y, Merola JF. Interleukin 17, inflammation, and cardiovascular risk in patients with psoriasis. J Am Acad Dermatol. 2018;79(2): 345-52.
15. Chiricozzi A, Romanelli P, Volpe E, Borsellino G, Romanelli M. Scanning the immunopathogenesis of psoriasis. Int J Mol Sci. 2018;19(1):E179.

16. Blauvelt A, Chiricozzi A. The immunologic role of IL-17 in psoriasis and psoriatic arthritis pathogenesis. Clin Rev Allergy Immunol. 2018;55(3):379-90.

17. Zaba LC, Suárez-Fariñas M, Fuentes-Duculan J, Nograles KE, Guttman-Yassky E, Cardinale I, et al. Effective treatment of psoriasis with etanercept is linked to suppression of IL-17 signaling, not immediate response TNF genes. J Allergy Clin Immunol. 2009;124(5):1022-30.e395.

18. Schmitz ML, Weber A, Roxlau T, Gaestel M, Kracht M. Signal integration, crosstalk mechanisms and networks in the function of inflammatory cytokines. Biochim Biophys Acta. 2011;1813(12): 2165-75.

19. Chiricozzi A, Guttman-Yassky E, Suárez-Fariñas M, Nograles KE, Tian S, Cardinale I, et al. Integrative responses to IL-17 and TNF-alpha in human keratinocytes account for key inflammatory pathogenic circuits in psoriasis. J Invest Dermatol. 2011;131(3):677-87.

20. Prignano F, Arnaboldi F, Cornaghi L, Landoni F, Tripo L, Preis FW, et al. Tumor necrosis factor-alpha and interleukin-17 differently affects Langerhans cell distribution and activation in an innovative three-dimensional model of normal human skin. Eur J Cell Biol. 2015;94(2):71-7.

21. Johnston A, Fritz Y, Dawes SM, Diaconu D, Al-Attar PM, Guzman AM, et al. Keratinocyte overexpression of IL-17C promotes psoriasiform skin inflammation. J Immunol. 2013;190(5):2252-62.

22. Zhang $\mathrm{X}$, Angkasekwinai $\mathrm{P}$, Dong C, Tang $\mathrm{H}$. Structure and function of interleukin-17 family cytokines. Protein Cell. 2011;2(1):26-40.

23. Keijsers RR, Joosten I, van Erp PE, Koenen HJ, van de Kerkhof PC. Cellular sources of IL-17 in psoriasis: a paradigm shift? Exp Dermatol. 2014;23(11): 799-803.

24. Lin AM, Rubin CJ, Khandpur R, Wang JY, Riblett M, Yalavarthi S, et al. Mast cells and neutrophils release IL-17 through extracellular trap formation in psoriasis. J Immunol. 2011;187(1):490-500.

25. Keijsers RR, Hendriks AGM, van Erp PEJ, van Cranenbroek B, van de Kerkhof PCM, Koenen HJPM, et al. In vivo induction of cutaneous inflammation results in the accumulation of extracellular trapforming neutrophils expressing ROR $\gamma \mathrm{t}$ and IL-17. J Invest Dermatol. 2014;134(5):1276-84. 
26. Dyring-Andersen B, Honoré TV, Madelung A, Bzorek M, Simonsen S, Clemmensen SN, et al. Interleukin (IL)-17A and IL-22-producing neutrophils in psoriatic skin. $\mathrm{Br} \mathrm{J}$ Dermatol. 2017;177(6):e321-2.

27. Tamassia N, Arruda-Silva F, Calzetti F, Lonardi S, Gasperini S, Gardiman E, et al. A reappraisal on the potential ability of human neutrophils to express and produce IL-17 family members in vitro: failure to reproducibly detect it. Front immunol. 2018;9: 795.

28. Chiricozzi A, Suárez-Fariñas M, Fuentes-Duculan J, Cueto I, Li K, Tian S, et al. Increased expression of interleukin-17 pathway genes in nonlesional skin of moderate-to-severe psoriasis vulgaris. Br J Dermatol. 2016;174(1):136-45.

29. Kuwabara T, Ishikawa F, Kondo M, Kakiuchi T. The role of IL-17 and related cytokines in inflammatory autoimmune diseases. Mediat Inflamm. 2017;2017: 3908061.

30. Krueger JG, Brunner PM. Interleukin-17 alters the biology of many cell types involved in the genesis of psoriasis, systemic inflammation and associated comorbidities. Exp Dermatol. 2018;27(2):115-23.

31. Krueger JG. An autoimmune "attack" on melanocytes triggers psoriasis and cellular hyperplasia. J Exp Med. 2015;212(13):2186.

32. Fuentes-Duculan J, Bonifacio KM, Hawkes JE, Kunjravia N, Cueto I, Li X, et al. Autoantigens ADAMTSL5 and LL37 are significantly upregulated in active psoriasis and localized with keratinocytes, dendritic cells and other leukocytes. Exp Dermatol. 2017;26(11):1075-82.

33. Cheuk S, Wikén M, Blomqvist L, Nylén S, Talme T, Ståhle M, et al. Epidermal Th22 and Tc17 cells form a localized disease memory in clinically healed psoriasis. J Immunol. 2014;192(7):3111-20.

34. Matos TR, O’Malley JT, Lowry EL, Hamm D, Kirsch IR, Robins HS, et al. Clinically resolved psoriatic lesions contain psoriasis-specific IL-17-producing $\alpha \beta$ T cell clones. J Clin Invest. 2017;127(11):4031-41.

35. Lee E, Trepicchio WL, Oestreicher JL, Pittman D, Wang F, Chamian F, et al. Increased expression of interleukin 23 p19 and p40 in lesional skin of patients with psoriasis vulgaris. J Exp Med. 2004;199(1):125-30.

36. Wechter T, Cline A, Feldman SR. Targeting p19 as a treatment option for psoriasis: an evidence-based review of guselkumab. Ther Clin Risk Manag. 2018;14:1489-97.
37. Liu W, Ouyang X, Yang J, Liu J, Li Q, Gu Y, et al. AP1 activated by toll-like receptors regulates expression of IL-23 p19. J Biol Chem. 2009;284(36): 24006-16.

38. Chiricozzi A, Saraceno R, Chimenti MS, GuttmanYassky E, Krueger JG. Role of IL-23 in the pathogenesis of psoriasis: a novel potential therapeutic target? Expert Opin Ther Targets. 2014;18(5): 513-25.

39. Chan TC, Hawkes JE, Krueger JG. Interleukin 23 in the skin: role in psoriasis pathogenesis and selective interleukin 23 blockade as treatment. Ther Adv Chronic Dis. 2018;9(5):111-9.

40. Chan JR, Blumenschein W, Murphy E, Diveu C, Wiekowski M, Abbondanzo S, et al. IL-23 stimulates epidermal hyperplasia via TNF and IL-20R2-dependent mechanisms with implications for psoriasis pathogenesis. J Exp Med. 2006;203(12):2577-87.

41. Puig L. The role of IL 23 in the treatment of psoriasis. Expert Rev Clinical Immunol. 2017;13(6): 525-34.

42. Yang EJ, Beck KM, Liao W. Secukinumab in the treatment of psoriasis: patient selection and perspectives. Psoriasis (Auckl). 2018;8:75-82.

43. Blauvelt A, Papp KA, Lebwohl MG, Green LJ, Hsu S, Bhatt $\mathrm{V}$, et al. Rapid onset of action in patients with moderate-to-severe psoriasis treated with brodalumab: a pooled analysis of data from two phase 3 randomized clinical trials (AMAGINE-2 and AMAGINE-3). J Am Acad Dermatol. 2017;77(2):372-4.

44. Giunta A, Ventura A, Chimenti MS, Bianchi L, Esposito M. Spotlight on ixekizumab for the treatment of moderate-to-severe plaque psoriasis: design, development, and use in therapy. Drug Des Devel Ther. 2017;11:1643-51.

45. Mylle S, Grine L, Speeckaert R, Lambert JLW, van Geel N. Targeting the IL-23/IL-17 pathway in psoriasis: the search for the good, the bad and the ugly. Am J Clin Dermatol. 2018;19(5):625-37.

46. Takeshita J, Grewal S, Langan SM, Mehta NN, Ogdie A, Van Voorhees AS, et al. Psoriasis and comorbid diseases: epidemiology. J Am Acad Dermatol. 2017;76(3):377-90.

47. Kivelevitch D, Schussler JM, Menter A. Coronary plaque characterization in psoriasis. Circulation. 2017;136(3):277-80.

48. Puig L. Cardiometabolic comorbidities in psoriasis and psoriatic arthritis. Int J Mol Sci. 2017;19(1):E58.

49. Armstrong AW, Voyles SV, Armstrong EJ, Fuller EN, Rutledge JC. A tale of two plaques: convergent 
mechanisms of T-cell-mediated inflammation in psoriasis and atherosclerosis. Exp Dermatol. 2011;20(7):544-9.

50. Abraham C, Dulai PS, Vermeire S, Sandborn WJ. Lessons learned from trials targeting cytokine pathways in patients with inflammatory bowel diseases. Gastroenterology. 2017;152(2):374-88.e4.

51. Langley RG, Elewski BE, Lebwohl M, Reich K, Griffiths CE, Papp K, et al. Secukinumab in plaque psoriasis-results of two phase 3 trials. N Engl J Med. 2014;371(4):326-38.

52. Griffiths CE, Reich K, Lebwohl M, van de Kerkhof P, Paul C, Menter A, et al. Comparison of ixekizumab with etanercept or placebo in moderate-to-severe psoriasis (UNCOVER-2 and UNCOVER-3): results from two phase 3 randomised trials. Lancet. 2015;386(9993):541-51.

53. Mease PJ, van der Heijde D, Ritchlin CT, Okada M, Cuchacovich RS, Shuler CL, et al. Ixekizumab, an interleukin-17A specific monoclonal antibody, for the treatment of biologic-naive patients with active psoriatic arthritis: results from the 24-week randomised, double-blind, placebo-controlled and active (adalimumab)-controlled period of the phase III trial SPIRIT-P1. Ann Rheum Dis. 2017;76(1): 79-87.

54. Roman M, Chiu MW. Spotlight on brodalumab in the treatment of moderate-to-severe plaque psoriasis: design, development, and potential place in therapy. Drug Des Devel Ther. 2017;11:2065-75.

55. Krueger JG, Fretzin S, Suárez-Fariñas M, Haslett PA, Phipps KM, Cameron GS, et al. IL-17A is essential for cell activation and inflammatory gene circuits in subjects with psoriasis. J Allergy Clin Immunol. 2012;130(1):145-54.e9.

56. Cai Y, Shen X, Ding C, Qi C, Li K, Li X, et al. Pivotal role of dermal IL-17-producing gammadelta T cells in skin inflammation. Immunity. 2011;35(4): 596-610.

57. Yiu ZZ, Warren RB. The potential utility of tildrakizumab: an interleukin-23 inhibitor for the treatment of psoriasis. Expert Opin Investig Drugs. 2017;26(2):243-9.

58. Gordon KB, Strober B, Lebwohl M, Augustin M, Blauvelt A, Poulin Y, et al. Efficacy and safety of risankizumab in moderate-to-severe plaque psoriasis (UltIMMa-1 and UltIMMa-2): results from two double-blind, randomised, placebo-controlled and ustekinumab-controlled phase 3 trials. Lancet. 2018;392(10148):650-61.

59. Cargill M, Schrodi SJ, Chang M, Garcia VE, Brandon $\mathrm{R}$, Callis $\mathrm{KP}$, et al. A large-scale genetic association study confirms IL12B and leads to the identification of IL23R as psoriasis-risk genes. Am J Hum Genet. 2007;80(2):273-90.

60. Blauvelt A, Papp KA, Griffiths CE, Randazzo B, Wasfi Y, Shen YK, et al. Efficacy and safety of guselkumab, an anti-interleukin-23 monoclonal antibody, compared with adalimumab for the continuous treatment of patients with moderate to severe psoriasis: results from the phase III, double-blinded, placeboand active comparator-controlled VOYAGE 1 trial. J Am Acad Dermatol. 2017;76(3):405-17.

61. Blauvelt A, Reich K, Tsai TF, Tyring S, Vanaclocha F, Kingo K, et al. Secukinumab is superior to ustekinumab in clearing skin of subjects with moderateto-severe plaque psoriasis up to 1 year: results from the CLEAR study. J Am Acad Dermatol. 2017;76(1): 60-9.e9.

62. D'Angelo S, Tramontano G, Gilio M, Leccese P, Olivieri I. Review of the treatment of psoriatic arthritis with biological agents: choice of drug for initial therapy and switch therapy for non-responders. Open Access Rheumatol. 2017;9:21-8.

63. Kim J, Krueger JG. Highly effective new treatments for psoriasis target the IL-23/type 17 T cell autoimmune axis. Ann Rev Med. 2017;68:255-69.

64. Papp KA, Merola JF, Gottlieb AB, Griffiths CEM, Cross N, Peterson L, et al. Dual neutralization of both interleukin $17 \mathrm{~A}$ and interleukin $17 \mathrm{~F}$ with bimekizumab in patients with psoriasis: results from BE ABLE 1, a 12-week randomized, double-blinded, placebo-controlled phase $2 \mathrm{~b}$ trial. J Am Acad Dermatol. 2018;79(2):277-86.e10.

65. Ritchlin CT, Kavanaugh A, Merola JF, Schett G, Scher JU, Warren RB, et al. Bimekizumab in patients with active psoriatic arthritis: results from a 48-week, randomised, double-blind, placebo-controlled, dose-ranging phase $2 \mathrm{~b}$ trial. Lancet. 2020;395(10222):427-40.

66. Reich K, Rich P, Maari C, Bissonnette R, Leonardi C, Menter A, et al. Efficacy and safety of mirikizumab (LY3074828) in the treatment of moderate-to-severe plaque psoriasis: results from a randomized phase II study. Br J Dermatol. 2019;181(1):88-95.

67. Sandborn WJ, Ferrante M, Bhandari BR, Berliba E, Feagan BG, Hibi T, et al. Efficacy and safety of mirikizumab in a randomized phase 2 study of patients with ulcerative colitis. Gastroenterology. 2020;158(3):537-49.e10.

68. Sands B, Sandborn W, Peyrin-Biroulet L, Higgins P, Hirai F, Belin R, et al. 1003 Efficacy and safety of mirikizumab (LY3074828) in a phase 2 study of patients with crohn's disease. Gastroenterology. 2019;156(6):S216. 
69. Mease PJ, Gladman DD, Papp KA, Khraishi MM, Thaçi D, Behrens F, et al. Prevalence of rheumatologist-diagnosed psoriatic arthritis in patients with psoriasis in European/North American dermatology clinics. J Am Acad Dermatol. 2013;69(5):729-35.

70. Gladman DD, Antoni C, Mease P, Clegg DO, Nash P. Psoriatic arthritis: epidemiology, clinical features, course, and outcome. Ann Rheum Dis. 2005;64(Suppl 2):14-7.

71. Haroon M, Gallagher P, FitzGerald O. Diagnostic delay of more than 6 months contributes to poor radiographic and functional outcome in psoriatic arthritis. Ann Rheum Dis. 2015;74(6):1045-50.

72. Gottlieb A, Korman NJ, Gordon KB, Feldman SR, Lebwohl M, Koo JY, et al. Guidelines of care for the management of psoriasis and psoriatic arthritis: section 2. Psoriatic arthritis: overview and guidelines of care for treatment with an emphasis on the biologics. J Am Acad Dermatol. 2008;58(5):851-64.

73. Raychaudhuri SP, Raychaudhuri SK, Genovese MC. IL-17 receptor and its functional significance in psoriatic arthritis. Mol Cell Biochem. 2012;359(1-2):419-29.

74. Suzuki E, Mellins ED, Gershwin ME, Nestle FO, Adamopoulos IE. The IL-23/IL-17 axis in psoriatic arthritis. Autoimmun Rev. 2014;13(4-5):496-502.

75. Yago T, Nanke Y, Ichikawa N, Kobashigawa T, Mogi M, Kamatani N, et al. IL-17 induces osteoclastogenesis from human monocytes alone in the absence of osteoblasts, which is potently inhibited by antiTNF-alpha antibody: a novel mechanism of osteoclastogenesis by IL-17. J Cell Biochem. 2009;108(4): 947-55.

76. Adamopoulos IE, Suzuki E, Chao CC, Gorman D, Adda S, Maverakis E, et al. IL-17A gene transfer induces bone loss and epidermal hyperplasia associated with psoriatic arthritis. Ann Rheum Dis. 2015;74(6):1284-92.

77. Yamamoto M, Nakajima K, Takaishi M, Kitaba S, Magata Y, Kataoka S, et al. Psoriatic inflammation facilitates the onset of arthritis in a mouse model. J Invest Dermatol. 2015;135(2):445-53.

78. Kotake S, Udagawa N, Takahashi N, Matsuzaki K, Itoh $\mathrm{K}$, Ishiyama S, et al. IL-17 in synovial fluids from patients with rheumatoid arthritis is a potent stimulator of osteoclastogenesis. J Clin Invest. 1999;103(9):1345-52.

79. Adamopoulos IE, Chao CC, Geissler R, Laface D, Blumenschein W, Iwakura Y, et al. Interleukin-17A upregulates receptor activator of NF- $\kappa \mathrm{B}$ on osteoclast precursors. Arthritis Res Ther. 2010;12(1):R29.
80. Raychaudhuri SP, Raychaudhuri SK. Mechanistic rationales for targeting interleukin-17A in spondyloarthritis. Arthritis Res Ther. 2017;19(1):51.

81. Shin HS, Sarin R, Dixit N, Wu J, Gershwin E, Bowman EP, et al. Crosstalk among IL-23 and DNAX activating protein of $12 \mathrm{kDa}$-dependent pathways promotes osteoclastogenesis. J Immunol. 2015;194(1):316-24.

82. Siegel EL, Orbai AM, Ritchlin CT. Targeting extraarticular manifestations in PsA: a closer look at enthesitis and dactylitis. Curr Opin Rheumatol. $2015 ; 27(2): 111-7$.

83. Martin DA, Towne JE, Kricorian G, Klekotka P, Gudjonsson JE, Krueger JG, et al. The emerging role of IL-17 in the pathogenesis of psoriasis: preclinical and clinical findings. $\mathrm{J}$ Invest Dermatol. 2013;133(1):17-26.

84. Wang EA, Suzuki E, Maverakis E, Adamopoulos IE. Targeting IL-17 in psoriatic arthritis. Eur J Rheumatol. 2017;4(4):272-7.

85. Mease $\mathrm{P}$, van der Heijde $\mathrm{D}$, Landewé R, Mpofu $\mathrm{S}$, Rahman P, Tahir H, et al. Secukinumab improves active psoriatic arthritis symptoms and inhibits radiographic progression: primary results from the randomised, double-blind, phase III FUTURE 5 study. Ann Rheum Dis. 2018;77(6):890-7.

86. McInnes IB, Mease PJ, Kirkham B, Kavanaugh A, Ritchlin CT, Rahman $P$, et al. Secukinumab, a human anti-interleukin-17A monoclonal antibody, in patients with psoriatic arthritis (FUTURE 2): a randomised, double-blind, placebo-controlled, phase 3 trial. Lancet. 2015;386(9999):1137-46.

87. Mease PJ, McInnes IB, Kirkham B, Kavanaugh A, Rahman P, van der Heijde D, et al. Secukinumab inhibition of interleukin-17A in patients with psoriatic arthritis. N Engl J Med. 2015;373(14):1329-39.

88. Nash P, Kirkham B, Okada M, Rahman P, Combe B, Burmester GR, et al. Ixekizumab for the treatment of patients with active psoriatic arthritis and an inadequate response to tumour necrosis factor inhibitors: results from the 24-week randomised, double-blind, placebo-controlled period of the SPIRIT-P2 phase 3 trial. Lancet. 2017;389(10086): 2317-27.

89. Mease PJ, Smolen JS, Behrens F, Nash P, Liu Leage S, $\mathrm{Li} \mathrm{L}$, et al. A head-to-head comparison of the efficacy and safety of ixekizumab and adalimumab in biological-naïve patients with active psoriatic arthritis: 24-week results of a randomised, open-label, blinded-assessor trial. Ann Rheum Dis. 2020;79(1):123-31. 
90. European Medicines Agency. Cosentyx [summary of product characteristics]. 2019. https://www.ema. europa.eu/en/documents/product-information/cos entyx-epar-product-information_en.pdf. Accessed 24 Oct 2019.

91. European Medicines Agency. Talz [summary of product characteristics]. 2019. https://www.ema. europa.eu/en/documents/product-information/taltzepar-product-information_en.pdf. Accessed 24 Oct 2019.

92. Deodhar A, Helliwell PS, Boehncke WH, Kollmeier AP, Hsia EC, Subramanian RA, et al. Guselkumab in patients with active psoriatic arthritis who were biologic-naive or had previously received $\mathrm{TNF} \alpha$ inhibitor treatment (DISCOVER-1): a double-blind, randomised, placebo-controlled phase 3 trial. Lancet. 2020;395(10230):1115-25.

93. Mease PJ, Rahman P, Gottlieb AB, Kollmeier AP, Hsia EC, Xu XL, et al. Guselkumab in biologic-naive patients with active psoriatic arthritis (DISCOVER2): a double-blind, randomised, placebo-controlled phase 3 trial. Lancet. 2020;395(10230):1126-36.

94. McKeage K, Duggan S. Risankizumab: first global approval. Drugs. 2019;79(8):893-900.

95. Ohtsuki M, Fujita H, Watanabe M, Suzaki K, Flack $\mathrm{M}$, Huang $\mathrm{X}$, et al. Efficacy and safety of risankizumab in Japanese patients with moderate to severe plaque psoriasis: results from the SustaIMM phase 2/3 trial. J Dermatol. 2019;46(8):686-94.

96. Humira ${ }^{\circledR}$ (adalimumab) [package insert]. Chicago, IL: AbbVie, Inc; 2020.

97. Enbrel ${ }^{\circledR}$ (etanercept) [package insert]. Thousand Oaks, CA: Immunex Corporation; 2020.

98. Taltz ${ }^{\circledR}$ (ixekizumab) [package insert]. Indianapolis, IN: Eli Lilly and Company; 2020.

99. Tremfya ${ }^{\circledR}$ (guselkumab) [package insert]. Horsham, PA: Janssen Biotech, Inc; 2020.

100. Cosentyx ${ }^{\circledR} \quad$ (secukinumab) [package insert]. East Hanover, NJ: Novartis Pharmaceuticals Corporation; 2020.

101. Henderson Berg $\mathrm{MH}$, Carrasco D. Injection site reactions to biologic agents used in psoriasis and psoriatic arthritis. J Drugs Dermatol. 2017;16(7): 695-8.

102. Armstrong EJ, Harskamp CT, Armstrong AW. Psoriasis and major adverse cardiovascular events: a systematic review and meta-analysis of observational studies. J Am Heart Assoc. 2013;2(2):e000062.
103. Mansouri B, Kivelevitch D, Natarajan B, Joshi AA, Ryan C, Benjegerdes K, et al. Comparison of coronary artery calcium scores between patients with psoriasis and type 2 diabetes. JAMA Dermatol. 2016;152(11):1244-53.

104. Mehta NN, Azfar RS, Shin DB, Neimann AL, Troxel $\mathrm{AB}$, Gelfand JM. Patients with severe psoriasis are at increased risk of cardiovascular mortality: cohort study using the General Practice Research Database. Eur Heart J. 2010;31(8):1000-6.

105. Singh S, Young P, Armstrong AW. An update on psoriasis and metabolic syndrome: a meta-analysis of observational studies. PLoS ONE. 2017;12(7): e0181039.

106. Mehta NN, Li K, Szapary P, Krueger J, Brodmerkel C. Modulation of cardiometabolic pathways in skin and serum from patients with psoriasis. J Transl Med. 2013;11:194.

107. Shlyankevich J, Mehta NN, Krueger JG, Strober B, Gudjonsson JE, Qureshi AA, et al. Accumulating evidence for the association and shared pathogenic mechanisms between psoriasis and cardiovascularrelated comorbidities. Am J Med. 2014;127(12): 1148-53.

108. Taleb S, Tedgui A, Mallat Z. IL-17 and Th17 cells in atherosclerosis: subtle and contextual roles. Arterioscler Thromb Vasc Biol. 2015;35(2):258-64.

109. Wang Y, Gao H, Loyd CM, Fu W, Diaconu D, Liu S, et al. Chronic skin-specific inflammation promotes vascular inflammation and thrombosis. J Invest Dermatol. 2012;132(8):2067-75.

110. Li Y, Golden JB, Camhi MI, Zhang X, Fritz Y, Diaconu $\mathrm{D}$, et al. Protection from psoriasis-related thrombosis after inhibition of IL-23 or IL-17A. J Invest Dermatol. 2018;138(2):310-5.

111. Wang Y, Golden JB, Fritz Y, Zhang X, Diaconu D, Camhi MI, et al. Interleukin 6 regulates psoriasiform inflammation-associated thrombosis. JCI Insight. 2016;1(20):e89384.

112. Dart ML, Jankowska-Gan E, Huang G, Roenneburg DA, Keller MR, Torrealba JR, et al. Interleukin-17dependent autoimmunity to collagen type $\mathrm{V}$ in atherosclerosis. Circ Res. 2010;107(9):1106-16.

113. Lim H, Kim YU, Sun H, Lee JH, Reynolds JM, Hanabuchi S, et al. Proatherogenic conditions promote autoimmune $\mathrm{T}$ helper 17 cell responses in vivo. Immunity. 2014;40(1):153-65.

114. Paust HJ, Turner JE, Steinmetz OM, Peters A, Heymann F, Hölscher C, et al. The IL-23/Th17 axis contributes to renal injury in experimental 
glomerulonephritis. J Am Soc Nephrol. 2009;20(5): 969-79.

115. Madhur MS, Lob HE, McCann LA, Iwakura Y, Blinder Y, Guzik TJ, et al. Interleukin 17 promotes angiotensin ii-induced hypertension and vascular dysfunction. Hypertension. 2010;55(2):500-7.

116. Kitching AR, Holdsworth SR. The emergence of TH17 cells as effectors of renal injury. Am Soc Nephrol. 2011;22(2):235-8.

117. McMaster WG, Kirabo A, Madhur MS, Harrison DG. Inflammation, immunity, and hypertensive endorgan damage. Circ Res. 2015;116(6):1022-33.

118. Varricchi G, Granata F, Loffredo S, Genovese A, Marone G. Angiogenesis and lymphangiogenesis in inflammatory skin disorders. J Am Acad Dermatol. 2015;73(1):144-53.

119. Krueger J, Pariser D, Lee P, Bagel J, Armstrong A, Muscianisi E, et al. Secukinumab treatment normalizes inflammatory markers and immune response and leads to clinical improvement in patients with psoriasis: findings from the primary analysis of the ObePso-S study [abstract]. 24th World Congress of Dermatology, Milan, Italy 10-15 June, 2019.

120. Mehta NN, Shin DB, Joshi AA, Dey AK, Armstrong AW, Duffin KC, et al. Effect of 2 psoriasis treatments on vascular inflammation and novel inflammatory cardiovascular biomarkers: a randomized placebocontrolled trial. Circ Cardiovasc Imaging. 2018;11(6):e007394.

121. Gelfand JM, Takeshita J, Dey A, Shin D, Noe M, Fuxench ZC, et al. A phase IV, randomized, doubleblind, placebo-controlled crossover study of the effects of ustekinumab on vascular inflammation in psoriasis (the VIP-U trial). J Investig Med. 2018;66: 697.

122. Gelfand JM, Shin DB, Alavi A, Torigian DA, Werner $\mathrm{T}$, Papadopoulos $\mathrm{M}$, et al. A phase IV, randomized, double-blind, placebo-controlled crossover study of the effects of ustekinumab on vascular inflammation in psoriasis (the VIP-U trial). J Invest Dermatol. 2020;140(1):85-93.e2.

123. Gelfand JM, Shin DB, Duffin KC, Armstrong AW, Blauvelt A, Tyring SK, et al. A randomized placebocontrolled trial of secukinumab on aortic vascular inflammation in moderate-to-severe plaque psoriasis (VIP-S). J Invest Dermatol. 2020;140(9):1784-93. e2.

124. Smith JA, Colbert RA. Review: The interleukin-23/ interleukin-17 axis in spondyloarthritis pathogenesis: Th17 and beyond. Arthritis Rheumatol. 2014;66(2):231-41.
125. Paine A, Ritchlin CT. Targeting the interleukin-23/ 17 axis in axial spondyloarthritis. Curr Opin Rheumatol. 2016;28(4):359-67.

126. Feld J, Chandran V, Haroon N, Inman R, Gladman D. Axial disease in psoriatic arthritis and ankylosing spondylitis: a critical comparison. Nat Rev Rheumatol. 2018;14(6):363-71.

127. Jethwa H, Bowness P. The interleukin (IL)-23/IL-17 axis in ankylosing spondylitis: new advances and potentials for treatment. Clin Exp Immunol. 2016;183(1):30-6.

128. Baeten D, Sieper J, Braun J, Baraliakos X, Dougados M, Emery P, et al. Secukinumab, an Interleukin-17A Inhibitor. Ankyl Spondylitis $\mathrm{N}$ Engl J Med. 2015;373(26):2534-48.

129. Deodhar A, Poddubnyy D, Pacheco-Tena C, Salvarani C, Lespessailles E, Rahman P, et al. Efficacy and safety of ixekizumab in the treatment of radiographic axial spondyloarthritis: sixteen-week results from a phase III randomized, double-blind, placebo-controlled trial in patients with prior inadequate response to or intolerance of tumor necrosis factor inhibitors. Arthritis Rheumatol. 2019;71(4):599-611.

130. Dougados M, Wei JC, Landewé R, Sieper J, Baraliakos X, Van den Bosch F, et al. Efficacy and safety of ixekizumab through 52 weeks in two phase 3, randomised, controlled clinical trials in patients with active radiographic axial spondyloarthritis (COAST$\mathrm{V}$ and COAST-W). Ann Rheum Dis. 2020;79(2): 176-85.

131. Braun J, Blanco R, Dokoupilova E, Gensler LS, Kivitz A, Hall S, et al. Secukinumab $150 \mathrm{mg}$ significantly improved signs and symptoms of non-radiographic axial spondyloarthritis: 52-week results from the phase III PREVENT study. Presented at: EULAR 2020; June 3-6, 2020:Abstract OP0106.

132. Deodhar A, van der Heijde D, Gensler LS, Kim TH, Maksymowych WP, Østergaard M, et al. Ixekizumab for patients with non-radiographic axial spondyloarthritis (COAST-X): a randomised, placebo-controlled trial. Lancet. 2020;395(10217):53-64.

133. Baeten D, Østergaard M, Wei JC, Sieper J, Jarvinen $\mathrm{P}$, Tam LS, et al. Risankizumab, an IL-23 inhibitor, for ankylosing spondylitis: results of a randomised, double-blind, placebo-controlled, proof-of-concept, dose-finding phase 2 study. Ann Rheum Dis. 2018;77(9):1295-302.

134. Eppinga $H$, Poortinga $S$, Thio HB, Nijsten TEC, Nuij VJAA, van der Woude CJ, et al. Prevalence and phenotype of concurrent psoriasis and inflammatory bowel disease. Inflamm Bowel Dis. 2017;23(10):1783-9. 
135. Reich K, Leonardi C, Langley RG, Warren RB, Bachelez $\mathrm{H}$, Romiti $\mathrm{R}$, et al. Inflammatory bowel disease among patients with psoriasis treated with ixekizumab: a presentation of adjudicated data from an integrated database of 7 randomized controlled and uncontrolled trials. J Am Acad Dermatol. $2017 ; 76(3): 441-8$.

136. Neurath MF. IL-23 in inflammatory bowel diseases and colon cancer. Cytokine Growth Factor Rev. 2019;45:1-8.

137. Schreiber S, Colombel JF, Feagan BG, Reich K, Deodhar AA, McInnes IB, et al. Incidence rates of inflammatory bowel disease in patients with psoriasis, psoriatic arthritis and ankylosing spondylitis treated with secukinumab: a retrospective analysis of pooled data from 21 clinical trials. Ann Rheum Dis. $2019 ; 78(4)$ :473-9.

138. Verstockt B, Ferrante M, Vermeire S, Van Assche G. New treatment options for inflammatory bowel diseases. J Gastroenterol. 2018;53(5):585-90.

139. Feagan BG, Panes J, Ferrante M, Kaser A, D'Haens GR, Sandborn WJ, et al. Risankizumab in patients with moderate to severe Crohn's disease: an openlabel extension study. Lancet Gastroenterol Hepatol. 2018;3(10):671-80.

140. Hueber W, Sands BE, Lewitzky S, Vandemeulebroecke M, Reinisch W, Higgins PD, et al. Secukinumab, a human anti-IL-17A monoclonal antibody, for moderate to severe Crohn's disease: unexpected results of a randomised, double-blind placebo-controlled trial. Gut. 2012;61(12): 1693-700.

141. Targan SR, Feagan B, Vermeire S, Panaccione R, Melmed GY, Landers C, et al. A randomized, double-blind, placebo-controlled phase 2 study of brodalumab in patients with moderate-to-severe Crohn's disease. Am J Gastroenterol. 2016;111(11): 1599-607.

142. Smith MK, Pai J, Panaccione R, Beck P, Ferraz JG, Jijon H. Crohn's-like disease in a patient exposed to anti-Interleukin-17 blockade (Ixekizumab) for the treatment of chronic plaque psoriasis: a case report. BMC Gastroenterol. 2019;19(1):162.

143. Lebwohl M, Strober B, Menter A, Gordon K, Weglowska J, Puig L, et al. Phase 3 studies comparing brodalumab with ustekinumab in psoriasis. N Engl J Med. 2015;373(14):1318-28.

144. Leonardi C, Maari C, Philipp S, Goldblum O, Zhang L, Burkhardt N, et al. Maintenance of skin clearance with ixekizumab treatment of psoriasis: three-year results from the UNCOVER-3 study. J Am Acad Dermatol. 2018;79(5):824-30.e2.

145. Foley P, Gordon K, Griffiths CEM, Wasfi Y, Randazzo B, Song $\mathrm{M}$, et al. Efficacy of guselkumab compared with adalimumab and placebo for psoriasis in specific body regions: a secondary analysis of 2 randomized clinical trials. JAMA Dermatol. 2018;154(6):676-83.

146. Armstrong AW, Vender R, Kircik L. Secukinumab in the treatment of palmoplantar, nail, scalp, and pustular psoriasis. J Clin Aesthet Dermatol. 2016;9(6):S12-6.

147. Gottlieb A, Sullivan J, van Doorn M, Kubanov A, You R, Parneix A, et al. Secukinumab shows significant efficacy in palmoplantar psoriasis: results from GESTURE, a randomized controlled trial. J Am Acad Dermatol. 2017;76(1):70-80.

148. Menter A, Warren RB, Langley RG, Merola JF, Kerr LN, Dennehy EB, et al. Efficacy of ixekizumab compared to etanercept and placebo in patients with moderate-to-severe plaque psoriasis and nonpustular palmoplantar involvement: results from three phase 3 trials (UNCOVER-1, UNCOVER-2 and UNCOVER-3). J Eur Acad Dermatol Venereol. 2017;31(10):1686-92.

149. Ryan C, Menter A, Guenther L, Blauvelt A, Bissonnette $R$, Meeuwis $K$, et al. Efficacy and safety of ixekizumab in a randomized, double-blinded, placebo-controlled phase IIIb study of patients with moderate-to-severe genital psoriasis. Br J Dermatol. 2018;179(4):844-52.

150. Georgakopoulos JR, Phung M, Ighani A, Yeung J. Efficacy and safety of switching to ixekizumab in secukinumab nonresponders with plaque psoriasis: a multicenter retrospective study of interleukin 17A antagonist therapies. J Am Acad Dermatol. 2018;79(1):155-7.

151. Bokor-Billmann T, Schäkel K. No need to change the drug class: ixekizumab- following secukinumabtherapy in psoriasis. J Dermatolog Treat. 2019;30(3): 216-20.

152. Bilal J, Berlinberg A, Bhattacharjee S, Trost J, Riaz IB, Kurtzman DJB. A systematic review and meta-analysis of the efficacy and safety of the interleukin (IL)12/23 and IL-17 inhibitors ustekinumab, secukinumab, ixekizumab, brodalumab, guselkumab and tildrakizumab for the treatment of moderate to severe plaque psoriasis. J Dermatol Treat. 2018;29(6):569-78.

153. Kamata M, Tada Y. Safety of biologics in psoriasis. J Dermatol. 2018;45(3):279-86. 